\title{
1. Introduction: putting the learning organization into context: an emerging research field Anders Örtenblad
}

You have just started reading a book about the learning organization idea and its applicability in and relevance to organizations in different contexts. I assume that you, to begin with, want to know how this book in itself is relevant and how it is different from other books on the learning organization; that is, what you can learn from this book. This introductory chapter addresses these issues.

The overall aim of this book is to pay attention to and acknowledge the study of the relevance of the learning organization idea to organizations in different contexts as an emerging research field, in terms of looking at previous studies (past), showing some relevant new works (present), and drawing up lines for further research (future). A more utilitarian aim is to offer knowledge (as well as support for further knowledge-seeking) on what organizations in various particular contexts need to do to become learning organizations or, if this is not recommendable, how the learning organization idea needs to be adapted to become relevant to organizations within a particular context.

The learning organization idea, and how it will be defined throughout this book, is further elaborated on in Chapter 2. As a background to the reading of this first chapter of the book, a short introduction to the idea might still be helpful. The term 'learning organization' has been here for quite some time now; it occurred in academic works on learning and development in relation to organization and management as far back as the 1970s (Örtenblad 2007a). However, it did not become an 'idea' in its own right until the late 1980s and early 1990s. The world-famous book The Fifth Discipline: The Art and Practice of the Learning Organization, authored by Peter Senge (1990), came to be synonymous with the learning organization idea despite the fact that the term 'learning organization' had occurred in book titles several years earlier (e.g., Garratt 1987). Senge's book gained enormous popularity and was the starting point for a huge number of other academic as well as more practice-oriented writings. A journal entitled The Learning Organization was launched a few years after Senge's book was published; it remains in existence today, now published 
by Emerald. Senge's book has been translated into various languages and gave rise to a wave of projects in many parts of the world, in which organizations within various industries aimed at turning themselves into learning organizations. The debate over the years regarding how to define a 'learning organization' as well as who would benefit from the idea has been quite intense. Quite a number of people have claimed that the learning organization is just a fashion (e.g. Furnham 2004; Glaser 1997) and that the idea is too vague to be useful in practice (Caldwell 2012; Grieves 2008). As will be discussed further on within this chapter, the present book can be seen as an argument in this debate. It takes a broad grip of the idea in that the definition of the learning organization used throughout the book is based

on a typology of existing definitions (Örtenblad 2002a, 2004a, 2011) and the relevance, as well as the irrelevance, of the idea is continuously scrutinized rather than taken for granted.

As a first section in this introductory chapter, I take up the relevance of studies of the learning organization in general; thereafter, I outline differences between this book and other works on the learning organization. As a final section, I introduce the remainder of the book in terms of the chapter contributions.

\section{IS THE 'LEARNING ORGANIZATION' STILL RELEVANT?}

Is there really a need for another book on the learning organization? Some might argue that there are already too many books on this topic or that the idea of the learning organization has seen its best days. Are they right? Well, I do not, of course, believe that they are; if I did, then you would not be presently reading the introduction to this book. While it is probably correct to say that the idea of the learning organization is hardly as popular among certain groups of people in some parts of the world as it once was, I believe that there are at least a few reasons to continue taking an interest in this idea or, for those who have not been interested in the idea before, to start taking an interest in it.

I start with some concrete arguments in support of the relevance of the idea. Firstly, at least in some parts of the world, the interest in the idea of the learning organization seems to be increasing. For instance, the first conference on research on organizational learning and the learning organization in China was held in 2008 (Chen et al. 2010, pp. 257-258). Actually, the Communist Party of China stresses the learning organization as the road ahead for itself and calls for building learning organizations within it at all levels (People's Publishing House 2010). In addition to Southeast Asia, the 
interest in the idea also seems to be increasing in other parts of the world. For instance, the number of articles that has lately been published on the relevance of the learning organization idea to organizations in the Arab world and the Middle East is, to say the least, extensive (e.g. Abu-Tineh 2011; Al-jawazneh \& Al-Awawdeh 2011; Al-Qutop et al. 2011; Khasawneh 2011; Nazari \& Pihie 2012; Sharifirad 2011). Secondly, organizations repeatedly prove their incapability to reflect on themselves. Examples of such organizations include nuclear power plants, oil companies, banks and, not least, universities, just to mention a few. These are, I believe, indicators that the learning organization idea indeed still is relevant.

The popularity of so-called management ideas or management fashions is often measured in quantitative terms by the number of articles that are published yearly (in academic journals) on the topic (e.g. Abrahamson 1996; Ponzi \& Koenig 2002; Ryan \& Hurley 2004; Spell 1999) (for a critique of such so-called PMI or print media indicators studies, see Benders et al. 2007). It is probably correct to suggest that the interest in the learning organization among Western academics in general has declined. However, while the decreasing number of publications may indicate that the management idea is no longer as fashionable as it once was, it says little or nothing about the relevance of the idea. It has been shown that even academics are sensitive to what is fashionable and, thus, have fashions themselves (Bort \& Kieser 2011). Therefore, their decreased level of interest in any certain topic can hardly be seen as an indicator of the decreased relevance of the idea.

If the learning organization is a management fashion, as some have argued (e.g. Furnham 2004; Glaser 1997), then one can assume that many have taken an interest in the idea purely because others did, and primarily for the purpose of gaining legitimacy, that is, to put themselves forward in a favourable light (these include, of course, those authors who connect to the learning organization idea only for the sake of legitimizing their work). Not only do ideas such as the learning organization have the potential to increase the technical efficiency (Abrahamson 1991) of the organizations that use them in an instrumental (Pelz 1978) way, but every fashionable management idea also has a symbolic function (see e.g. Abrahamson 1991; Meyer \& Rowan 1977; Pelz 1978). My belief is that after the 'hype' that any fashionable management idea comes with, there should be time to explore more reflectively what the management idea can contribute in an instrumental sense. As a matter of fact, the best time to explore what the 'fashion' actually has to offer and can contribute might be right after the first fashion wave has faded off. For this reason, the focus in this book will mainly be on the instrumental use of the idea of the learning organization, in contrast to its symbolic use. 


\section{WHAT MAKES THIS BOOK UNIQUE?}

This book is different from other books on the learning organization in, mainly, three respects: it is more pragmatic, it puts the idea into context, and it has a vision of creating a contingency model of the relevance of the learning organization idea to organizations in various contexts.

\section{A Pragmatic Perspective}

While it might be easier and more comfortable for academics to see things in black and white, thus either viewing the learning organization idea as an ideal well worth striving for or, in as uncritical a way as blindfolded supporters see it, dismissing the learning organization as being 'just' a fashion (e.g. Furnham 2004; Glaser 1997), the overall approach taken in this book is a more 'critically reflexive' one. Accordingly, unlike the majority of other works on the learning organization, this book will not start with a list of reasons for why it is necessary for any organization to become a learning organization. Organizations are often promised all sorts of benefits from adopting the learning organization idea, such as gaining organizational effectiveness (Pettinger 2002, p.1) and excelling in the future (Senge 1990, p. 4). In contrast, organizations that dismiss the idea are 'doomed to failure' (Stata 1994, p.iii) and will not be able to survive: 'If we are to survive - individually or as companies, or as a country - we must create a tradition of "learning companies". Every company must be a "learning company" (Geoffrey Holland, then Director of the Manpower Services Commission, quoted in Pedler et al. 1991, p.ix).

Examples of industries and sectors within which it has been claimed that organizations in general need to or must become learning organizations include (but are not limited to) healthcare (e.g. Pennbrant et al. 2012), nursing (Jacobs et al. 1998), higher education (e.g. Brown 1992; Tam 1999), academic libraries (Riggs 1997), the non-profit sector (Hayes 2002), non-governmental organizations (NGOs) (e.g. Eade \& Ligteringen 2001), the church (Jarvis 2004), religious organizations (Carroll 2000), schools (e.g. Lingard et al. 2000; Tiana Ferrer 2010), the military (Haugrud et al. 2001), courts (Parker 1998), business organizations (Dingle 1995) and design consultancies (Ashton \& Johnstone 2003). In this sense the literature claims that the learning organization idea is universally applicable.

There is also a darker side to it. The learning organization has, for instance, earned criticism that it is an expression of informal power and control (Coopey 1995; Pant 2001) and that there is a clear limit to the critical reflection that the employees in a learning organization are expected to undertake (Fenwick 1998). As much as I believe that such criticism is 
relevant, I do, on the other hand, agree with the many who believe that the learning organization idea also brings valuable insights. To 'either idealize or marginalize managerial rationality' (Sturdy 2004, p. 155), as is the tendency within studies of the adoption of management ideas, is simply not the focus of this book. This book has a more constructive yet reflective and critically examining orientation. As Driver (2002) did in her refreshing article 'The learning organization: Foucauldian gloom or utopian sunshine?' but unlike the many researchers who tend to show scepticism towards management ideas like the learning organization (cf. Nicolai \& Röbken 2005, pp.416-417), this book's basic assumption is, in agreement with authors such as Kieser (1997), Collins (2000) and Sorge and van Witteloostuijn (2004, p. 1208), that management fashions might actually add at least some value to the organizations in which they are used and, thus, that there are both pros and cons to the learning organization idea.

\section{A Contextual Perspective}

How do you know what to do first, second, or third in this Fieldbook? No simple recipe can tell you, because everyone's needs are different. (Senge et al. 1994, p. 15)

Given the increased attention that has been paid to the context in management and organization studies for quite some time now (e.g. Adler 1983; Guillen 1994; Johns 2001; March 2005; Redding 1994), I do not seem to be alone in believing that the context needs to be taken into account when advising on the relevance of the learning organization idea. By 'context', I refer to a collection of implicit assumptions about a particular setting, its meaning and quality (Firat 2003). Contextual knowledge, when taken from one context or setting, can be recontextualized, which involves a sophisticated discursive shift in which a discourse generated in one context produces different meanings and consequences when imposed in an alternative context (Asimakou \& Oswick 2010), or decontextualized, that is, when knowledge is transferable across situations (Ackermann 1991). In the latter case, knowledge is removed from a particular context such that the implicit assumptions and contextual knowledge become separate from the immediate here-and-now setting, thereby losing their contextuality and, according to Ackermann (1991), becoming abstract.

Many of the most recognized authors on the learning organization idea explicitly express that there is no distinct end to the process of 'becoming a learning organization'. For instance, Watkins and Golembiewski (1995, p. 99) describe the learning organization in terms of a never-ending journey; Senge et al. (1994, pp. 5-6) talk about the learning organization in terms of a vision; Garratt (2001, p.x) presents the learning organization as 
a continuing aspiration; and Marsick and Watkins (1999, p.219) suggest that the learning organization must never be thought of as the real destination. Their statements imply that the learning organization idea might have to be modified so as to be relevant in various contexts; at the very least, such modifications should be considered.

However, neither the works referred to above nor the many works that, on the one hand, strongly recommend the adoption of the learning organization and, on the other hand, encourage each single organization to create its own, unique learning organization (e.g. Hawkins 1994, p.79; Jones \& Hendry 1992, p. 51; Marquardt \& Reynolds 1994, p. 109; Pedler \& Aspinwall 1998, p.2; Pedler et al. 1991, p.2; Senge et al. 1994, p.15; Swieringa \& Wierdsma 1992, p. 72; Watkins \& Marsick 1993, p. 8), specify which changes the learning organization idea needs to undergo to fit in with the specific organization and context.

Accordingly, all those considering turning their organization into a learning organization can be said, depending on where one comes from, to either have a large degree of freedom (see e.g. Alvarez 1998; Røvik 1996; Scarbrough \& Swan 2001) or be helplessly in need of assistance from consultants or researchers in adapting the idea (cf. Scarbrough \& Swan 2001, p. 8). Perhaps it is due to these reasons that many have, throughout the years, pointed out that the learning organization idea is vague and/ or ambiguous (e.g. Caldwell 2012; Easterby-Smith 1990; Filipczak 1993; Grieves 2000, 2008; Lipshitz et al. 1996; Smith 1999; Stewart 1994).

Even if vagueness and ambiguity can definitely contribute to creativity, for instance in the sense that vague management ideas can more easily be adapted to different contexts (e.g. Alvarez 1998, p. 43; Røvik 1996, p. 142; Scarbrough \& Swan 2001, p. 8), there is a risk that essential and even vital elements of the particular idea may not be adopted or that elements that would be fatal for the organization may be adopted. One cannot simply assume that an organization that legitimizes itself through a certain fashionable management idea has actually implemented the idea as described by a certain author (Nicolai \& Röbken 2005). For a couple of reasons, I am reluctant to completely trust the organizations' own ability to learn, that is, their 'absorptive capacity' (Cohen \& Levinthal 1990; EasterbySmith et al. 2008). One reason for suggesting that researchers interfere (Abrahamson 1996; see also Birkinshaw et al. 2008) by engaging in advising on the relevance of the learning organization idea, rather than leaving this to organizational actors (or consultants), is that organizational actors can be assumed to often lack the ability or knowledge to adapt the learning organization idea themselves. Another reason is that managers may adopt a version of the learning organization that supports their own individual interest rather than the interests of other stakeholders, such as 
the employees, the shareholders or the society. Researchers can generally be assumed to be less biased. Moreover, like any vague and ambiguous idea, the learning organization idea can be used for seductive purposes; the managers can present different versions of the idea to different groups, and thereby the same vague idea can satisfy different interests (see e.g. Astley \& Zammuto 1992; Kelemen 2000).

Thus, to ensure a sound balance between adoption and adaptation, researchers should engage in, as I call it, 'researcher-assisted adaptation'. ${ }^{1}$ The exact output of such critical examination might vary from case to case. The organizations within a particular context might be advised to change to become more like learning organizations, the learning organization idea might have to be modified to better fit the organizations in the context, changes to both the idea and the context/organizations might be suggested, or no changes whatsoever may be recommended. The organizations in a specific context might already be learning organizations, whereas the organizations within another context might be less or not at all so. The learning organization idea might be more relevant to organizations within a certain context than to organizations within another context. Some answers to these and similar questions will be offered further on in this book.

\section{Towards a Contingency Model of the Learning Organization}

Even if it might not be reasonable to request researchers to customize the learning organization idea to each individual organization's needs, there is definitely a reason to conduct research to investigate the relevance of the idea in relation to different general contextual variables and dimensions and, if necessary, to adapt it accordingly. Not only do I suggest that researchers take the context into account more generally when advising on the relevance of the learning organization idea to organizations within any individual context, but I also suggest that researchers apply a 'contingency approach', defined as 'reasoning that considers practice to be relative to a specific situation at hand. The epitome of contingency reasoning is the judicious refinement of situational relativity' (Sorge \& van Witteloostuijn 2004, p. 1206). As I have argued elsewhere (Örtenblad 2004b, 2007b), the time has come to start to more systematically contribute to the outlining of a contingency model that identifies in which situations which aspect(s) or type(s) of the learning organization idea is/are relevant and preferable, and in which situations it/they is/are not. Thus, researchers should assist in advising on the relevance and, potentially, the adaptation of decontextualized versions of the learning organization to organizations within specific contexts and, ultimately, in contributing to the construction of a 


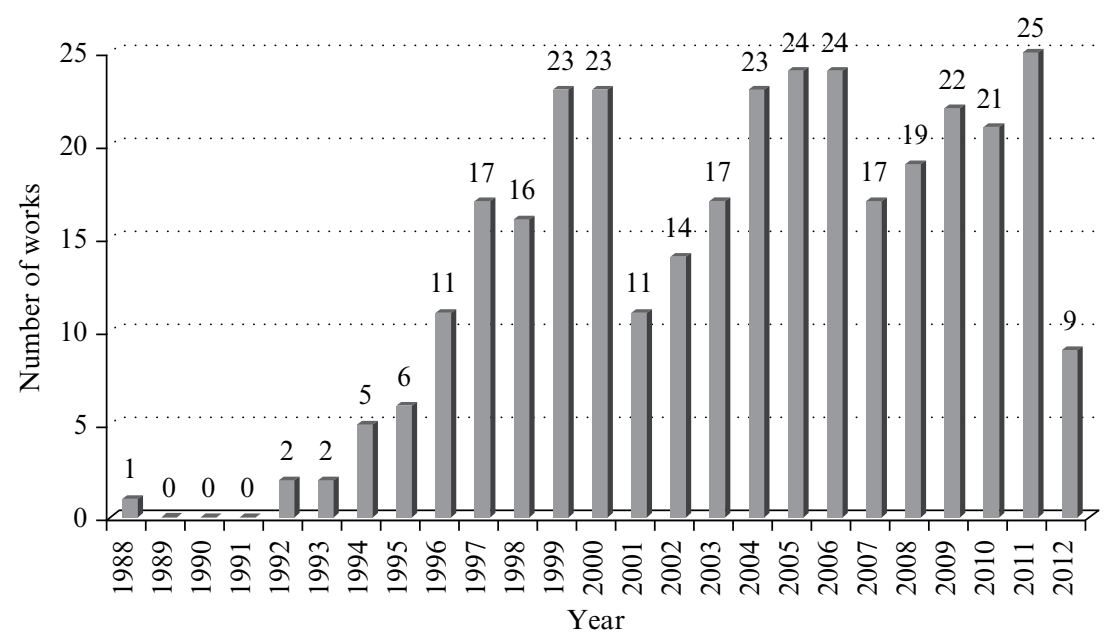

Note: The search was conducted on 27 April 2012 - see Chapter 3 in this volume for further details.

Figure 1.1 Number of works (total 332), on the learning organization idea in relation to a specific context, published between 1988 and 2012

contingency model of the relevance of the learning organization idea to organizations in different contexts.

In fact, there are already quite a number of existing works in which the learning organization idea is put into context (Figure 1.1). Even before Peter Senge's groundbreaking book on the learning organization was first published in 1990, the relevance of the learning organization idea was already being examined in relation to business schools (Ashton 1988). Thereafter, a relatively large number of works have been published in which the learning organization idea is somehow related to organizations within certain contexts. However, the large majority of these works can generally be regarded as isolated contributions (as will be taken up in more depth in Chapters 3 and 4) rather than as systematically contributing to a contingency model. The main problem is that different scholars have used different definitions of the learning organization idea, and because many of them consider the learning organization to be an ideal that does not need to be critically examined, their works cannot easily be compared, nor can their conclusions be added into a contingency model.

The vision is simply to move this emerging research field away from a situation where it is impossible to tell whether the incongruences between recommendations in different studies are explainable by the fact that the 
researchers have used different methods or research designs (see Chapter 4), applied different stakeholder perspectives (see Chapter 18), used different frames of reference (i.e., different definitions of the learning organization), studied different industries (such as schools and police agencies), or investigated industries located within different national cultures (such as China and Lebanon) (see, especially, Chapter 6). For instance, let us say that one study recommends that Chinese banks should become learning organizations, whereas another study suggests that universities in the United Kingdom (UK) should avoid adopting the learning organization idea; is the difference in recommendations due to different definitions, industries or national cultures?

\section{Target Groups}

I have argued elsewhere (Örtenblad 2010) that the existence and development of a contingency model of the relevance of the learning organization idea to organizations in various contexts might not be favourable from all perspectives or for all stakeholders. One can assume that a contingency model decreases the vagueness of the learning organization idea, something that might not be approved of by everybody, especially by those who intend to use the idea symbolically. To show the organization in a favourable light and thereby legitimize it (see e.g. Meyer \& Rowan 1977) might be a more difficult project as the idea gets clarified and simplified through a contingency model, and the opportunities for decoupling are diminished.

Nevertheless, one can assume that at least two groups of people might have an interest in the construction and launch of such a contingency model. Firstly, those who are interested in adopting the learning organization idea and using it instrumentally for increased technical efficiency are likely to take an interest in such knowledge. Through a contingency model, they can get some assistance in choosing a variant of the idea that is appropriate for their interest, be it profit maximization, increased well-being, societal effectiveness or welfare (Örtenblad 2011, and Chapter 18 in this volume), or any other interest. This reasoning is based on the presumption that management ideas' 'clear structure permits swift and precise action' (Fink 2003, p.47).

Secondly, the simplification and unambiguity that a contingency model containing adaptation guidelines could be assumed to bring about could supply a voice to those groups that might be seduced by the ambiguity that the idea otherwise possesses. Kelemen (2000) suggests that when employees do not understand what is going on at the top level, they stick together and attempt to find meanings concerning ideas of survival, creating an 'anti-language' usually characterized by clarity and specificity and 


\section{Handbook of research on the learning organization}

thereby differentiated from the ambiguous language. Thus, the power of the ambiguity used by managers, for instance, would be radically reduced. Such clear language could be provided through the development of a contingency model.

\section{THE REMAINDER OF THIS BOOK}

Not all authors who have contributed to this book necessarily agree that the learning organization idea always needs to be contextualized, but this is as it should be in a 'learning book'. At the very least, however, I dare to claim that all the authors agree that the context should be considered.

\section{Part I: Introduction and Background}

Part I of the book comprises an introduction and background. In addition to the current chapter, I present in Chapter 2, 'What do we mean by "learning organization"?', a definition of the learning organization that we have consistently stuck to as a starting point throughout this book, which makes it possible to draw comparisons between different chapters. In an effort to cover many definitions, this 'overview definition' is broad and contains four aspects/types of the learning organization. Chapter 3, 'Putting the learning organization into context: contributions from previous works', summarizes previous studies on the relevance of the learning organization idea to organizations in particular contexts. Although my co-authors and I had hoped that the literature review would result in at least a first major step towards the construction of a contingency model of the relevance of the learning organization idea to organizations in various contexts, we had to rethink our approach to some extent. Thus, the chapter now focuses instead on the reasons for why we had to abandon the idea of constructing a contingency model based on the findings from the literature review, although we also summarize some recommendations from previous literature regarding what organizations within particular contexts need to do to become learning organizations. Chapter 4, 'Contextualizing the learning organization: approaches to research design', is also (like Chapter 3) based on a review of previous literature within the field; however, in this chapter I take a closer look at how the studies have been conducted and, in particular, how the research has been designed. Various types of research designs are taken up, and their usefulness for the kind of study that the book takes up is evaluated and discussed. In Chapter 5, 'Obstacles to the learning organization', David Weir and myself discuss the reasons for why the learning organization idea has 
to a larger extent not been put into practice, and suggest how the obstacles to its implementation could be overcome.

\section{Part II: The Learning Organization in Context}

Part II of the book contains chapters on the relevance of the learning organization idea to certain contexts, and consists of three subsections. Table 1.1 offers an overview and comparison of the chapters in Part II in terms of the context they have studied, the main questions they have addressed, and the main sources they are based on.

Section A focuses on national culture and religion. In Chapter 6, 'National culture and the learning organization: an integrative framework', Pavel Bogolyubov and Mark Easterby-Smith argue that there is a need to take the national culture into account when adopting the learning organization idea, and suggest a framework for how this can be accomplished. In Chapter 7, 'Developing learning organizations in China', authors Jacky F.L. Hong, Robin Stanley Snell and Mian Lin discuss whether or not the learning organization idea is of relevance to organizations within China, a nation that lately has gained increased interest within the business area due to its rapidly developing economy, among other things. Chapter 8, 'Learning organization practices in Mexico: an empirical study' authored by David Joaquín Delgado-Hernández and Made Torokoff-Engelbrecht, deals with another developing country, Mexico, which so far has gained less attention in relation to the learning organization idea. In Chapter 9, 'Islamic perspective of the learning organization', Aini Ahmad connects the learning organization with religion, and outlines what a learning organization would need to be like from an Islamic perspective. Ahmad's chapter is one of the very few works that connect the learning organization idea to religion (see also Ahmad's previous works: Ahmad 2010, 2011; and one article on Jewish institutions as Jewish learning organizations: Lee 1998).

Section B takes up the relevance of the learning organization idea to various industries and sectors. In Chapter 10, 'Learning, trust and change within the Australian Army: the development of the Army Learning Organization Questionnaire (ALOQ)', Maya Drobnjak, Christina Stothard, Steven Talbot, Karen E. Watkins and Denise McDowall discuss whether or not the army is already a learning organization and outline a version of the famous DLOQ (Dimensions of the Learning Organization Questionnaire) adapted specifically to investigate whether or not the army is a learning organization and, if so, to what extent it is so. One sector that seems to have at least some similarities with the army is the police force, which is taken up in Chapter 11, 'The police force: to be or not 


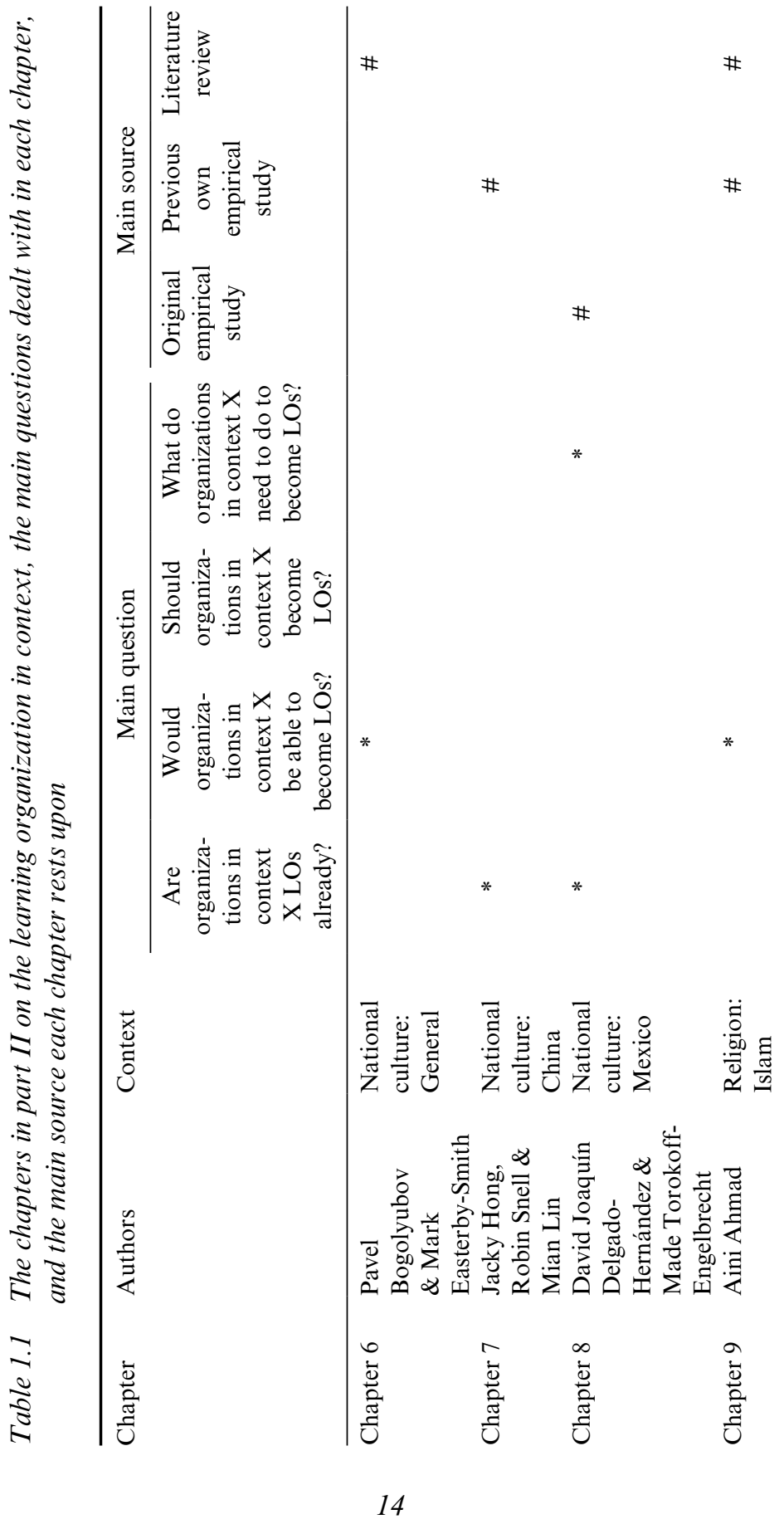


泀莺

疍

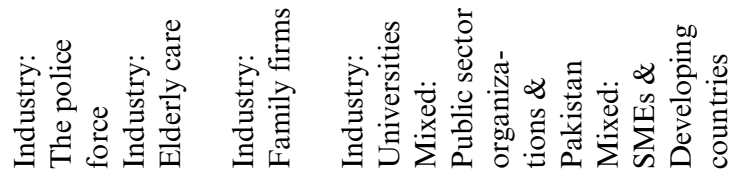
茪

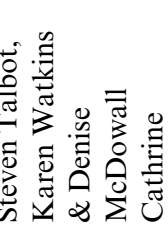

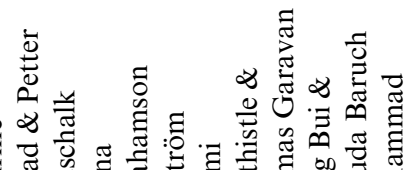

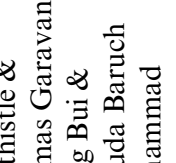

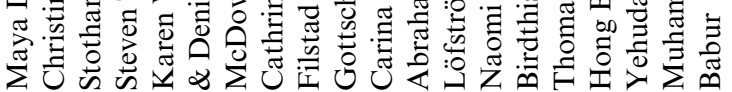

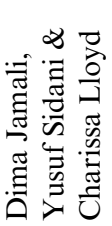

올

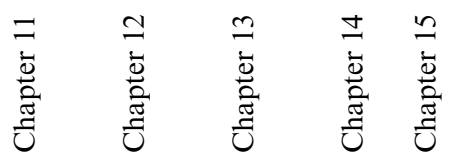

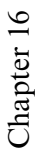


to be a learning organization?', authored by Cathrine Filstad and Petter Gottschalk. Like the army, the police force has previously not received much attention in relation to the learning organization. Chapter 12, 'The learning organization in elderly care - can it fit?' deals with the subsector 'elderly care', which has been less acknowledged in connection to the learning organization compared to the healthcare sector of which it is part. The author, Carina Abrahamson Löfström, is not convinced that the learning organization idea is fully relevant to elderly care organizations. Chapter 13, 'Family firms as learning organizations', deals with another type of company that has not gained a lot of attention, although the authors, Naomi Birdthistle and Thomas Garavan, have previously contributed to the research with works on small and medium-sized enterprises (SMEs) and the learning organization. In Chapter 14, 'Universities as learning organizations: internationalization and innovation', Hong Bui and Yehuda Baruch summarize prior knowledge and give some new insights on the relevance of the learning organization idea to the higher education sector, which has previously received considerable attention in this regard.

Section C includes chapters that explicitly deal with more than one contextual variable and in which the authors attempt to discuss the relevance of the learning organization idea not only to a particular industry but to a particular industry within a particular part of the world. Chapter 15, 'Public sector organizations as learning organizations: insights from the education system in Pakistan' takes up the public sector, which as such has received considerable attention. In this chapter the author, Muhammad Babur, explores whether or not public sector organizations in the Pakistani context are already learning organizations. In Chapter 16 , 'The learning organization: opportunities and challenges for small and medium-sized enterprises in developing countries', Dima Jamali, Yusuf Sidani and Charissa Lloyd report on whether or not SMEs in developing countries are already learning organizations, as well as what they would need to do to become more so.

\section{PART III: REFLECTIONS ON THE LEARNING ORGANIZATION}

Part III of the book contains chapters in which the authors reflect on either the learning organization in general or the previous parts of the book (especially the chapters in Part II). Chapter 17, 'The universality of learning company principles: a critical realist approach', provides a critical discussion of the universality of the learning organization idea. Although the approach generally taken in the book is that it cannot be taken for 
granted that the idea is universally applicable, John Burgoyne, the author of this chapter, is of a somewhat different opinion. In Chapter 18, 'Who is the learning organization for? A stakeholder contingency approach to contextualizing managerial panaceas', I argue that the relevance of the learning organization idea is not only dependent on which national culture and industry the organization exists in, but also on which stakeholder perspective is taken. Thereafter, two chapters each present an alternative conceptualization of the learning organization. As I have indicated in my previous work (Örtenblad 2002b), the critics of management ideas such as organizational learning and the learning organization rarely suggest alternative versions of the ideas; they almost always stick to criticizing the same versions of the ideas that are put forward by the protagonists. However, Chapters 19 and 20 present two interesting alternative conceptualizations of what a learning organization might be. In Chapter 19, “"The learning organization" - drop the dead metaphor! Per-forming organizing and learning in networks (so to speak)', Chris Blantern, Tom Boydell and John Burgoyne suggest an important but perhaps less controversial development of the learning organization idea, whereas Shih-wei Hsu's contribution in Chapter 20, 'Alternative learning organization', is definitely more radical. To certify that the conclusions of the book do not all come from the same single mind, I have invited Deborah Ann Blackman to draw conclusions from, and to comment upon, previous parts of the book. Her comments and conclusions are presented in Chapter 21, 'Contextualizing the learning organization: how will it help us learn in the future?', in which she outlines some advice on how the context could be taken into account in further research on the learning organization. Nevertheless, the final word in the book is my own. In Chapter 22, 'Towards a contingency model: recommendations for further research', I mainly outline suggestions for how future research on the relevance of the learning organization idea to organizations in different contexts might best be performed.

\section{NOTE}

1. I was inspired, in suggesting this term, by Røvik's distinction between 'rationally calculated translation' and 'unintentional translation' (Røvik 1998; see also Røvik 2011).

\section{REFERENCES}

Abrahamson, E. (1991), 'Managerial fads and fashions: the diffusion and rejection of innovations', Academy of Management Review, 16 (3), 586-612. 
Abrahamson, E. (1996), 'Management fashion', Academy of Management Review, 21 (1), 254-285.

Abu-Tineh, A.M. (2011), 'Exploring the relationship between organizational learning and career resilience among faculty members at Qatar University', International Journal of Educational Management, 25 (6), 635-650.

Ackermann, Edith K. (1991), 'From decontextualized to situated knowledge: revisiting Piaget's water-level experiment', in Idit Harel and Seymour Papert (eds), Constructionism, Norwood, NJ: Ablex Publishing Corporation, pp. 367-379.

Adler, N.J. (1983), 'A typology of management studies involving culture', Journal of International Business Studies, 14 (2), 29-47.

Ahmad, A. (2010), 'Commentary of Senge's Fifth Discipline from Islamic perspective', International Journal of Learning and Change, 4 (1), 7-20.

Ahmad, A. (2011), 'The learning organization from Islamic perspectives: a case study of two Islamic organizations in Malaysia', Doctoral dissertation, Lancaster University, Department of Management Learning and Leadership.

Al-jawazneh, B.E. and W.M. Al-Awawdeh (2011), 'Measuring the degree of the presence of learning organization dimensions at the branches of commercial banks in the gorvernorate of Almafrag, Jordan', International Journal of Business and Management, 6 (11), $27-38$

Al-Qutop, M.Y., S.M. Futa and A.I. Ma'ani (2011), 'The relationship between learning facilitators and transforming into a learning organization: an empirical study of the insurance sector in Jordan', International Business Research, 4 (3), 211-220.

Alvarez, José L. (1998), 'The sociological tradition and the spread and institutionalization of knowledge for action', in José L. Alvarez (ed.), The Diffusion and Consumption of Business Knowledge, London: Macmillan, pp. 13-57.

Ashton, D. (1988), 'Are business schools good learning organisations? Institutional values and their effects in management education', Personnel Review, 17 (4), 9-14.

Ashton, P. and I. Johnstone (2003), 'Transforming design consultancies through learning', Design Management Journal, 14 (3), 72-77.

Asimakou, T. and C. Oswick (2010), 'The recontextualization of commercialization: the shifting discourse of an R\&D unit', International Journal of Sociology and Social Policy, $30(5-6), 280-291$.

Astley, W.G. and R.F. Zammuto (1992), 'Organization science, managers and language games', Organization Science, 3 (4), 443-460.

Benders, J., J. Nijholt and S. Heusinkveld (2007), 'Using print media indicators in management fashion research', Quality and Quantity, 41 (6), 815-829.

Birkinshaw, J., G. Hamel and M.J. Mol (2008), 'Management innovation', Academy of Management Review, 33 (4), 825-845.

Bort, S. and A. Kieser (2011), 'Fashion in organization theory: an empirical analysis of the diffusion of theoretical concepts', Organization Studies, 32 (5), 655-681.

Brown, H. (1992), 'Staff development in higher education: towards the learning organisation?', Higher Education Quarterly, 46 (2), 174-190.

Caldwell, R. (2012), 'Systems thinking, organizational change and agency: a practice theory critique of Senge's learning organization', Journal of Change Management, 12 (2), 145-164.

Carroll, J.W. (2000), 'Reflexive ecclesiology: a challenge to applied research in religious organizations', Journal for the Scientific Study of Religion, 39 (4), 545-557.

Chen, G., N. Ning, L. Li and H. Zhao (2010), 'The current state and future directions of research and practice in organizational learning and learning organizations in China', Frontiers of Business Research in China, 4 (2), 231-261.

Cohen, W. and D.A. Levinthal (1990), 'Absorptive capacity: a new perspective on learning and innovation', Administrative Science Quarterly, 35 (1), 128-152.

Collins, David (2000), Management Fads and Buzzwords: Critical-Practical Perspectives, London: Routledge.

Coopey, J. (1995), 'The learning organization, power, politics and ideology', Management Learning, 26 (2), 193-213. 
Dingle, J. (1995), 'Analysing the competence requirements of managers', Management Development Review, 8 (2), 30-36.

Driver, M. (2002), 'The learning organization: Foucauldian gloom or utopian sunshine?', Human Relations, 55 (1), 33-53.

Eade, Deborah and Ernst Ligteringen (2001), 'NGOs and the future: taking stock, shaping debates, changing practice', in Deborah Eade and Ernst Ligteringen (eds), Debating Development: NGOs and the Future, Oxford: Oxfam GB, pp. 11-18.

Easterby-Smith, M. (1990), 'Creating a learning organisation', Personnel Review, 19 (5), 24-28.

Easterby-Smith, M., M. Graça, E. Antonacopoulou and J. Ferdinand (2008), 'Absorptive capacity: a process perspective', Management Learning, 39 (5), 483-501.

Fenwick, Tara (1998), 'Questioning the concept of the learning organization', in Sue M. Scott, Bruce Spencer and Alan M. Thomas (eds), Learning for Life: Canadian Readings in Adult Education, Toronto: Thompson, pp. 140-152.

Filipczak, B. (1993), 'I am a learning organization', Training, 30 (12), 10.

Fink, D. (2003), 'A life cycle approach to management fashion: an investigation of management concepts in the context of competitive strategy', Schmalenbach Business Review, 55 (1), 46-59.

Firat, Aykut (2003), 'Information integration using contextual knowledge and ontology merging', Doctoral dissertation, Cambridge, MA: Massachusetts Institute of Technology.

Furnham, Adrian (2004), Management and Myths: Challenging Business Fads, Fallacies and Fashions, New York: Palgrave Macmillan.

Garratt, Bob (1987), The Learning Organization, London: Harper Collins.

Garratt, Bob (2001), The Learning Organization: Developing Democracy at Work, London: Harper Collins.

Glaser, S. (1997), 'Management duckspeak', Management Decision, 35 (9), 653-655.

Grieves, J. (2000), 'Navigating change into the new millennium: themes and issues for the learning organization', Learning Organization, 7 (2), 54-74.

Grieves, J. (2008), 'Why we should abandon the idea of the learning organization', Learning Organization, 15 (6), 463-473.

Guillen, M.F. (1994), 'The age of eclecticism: current organizational trends and the evolution of managerial models', Sloan Management Review, 36 (1), 75-86.

Haugrud, A., G.C. Lehmann and C. Phillips (2001), 'Rethinking joint training', Joint Force Quarterly, 27, 66-70.

Hawkins, P. (1994), 'Organizational learning: taking stock and facing the challenge', Management Learning, 25 (1), 71-82.

Hayes, T. (2002), 'The non-profit sector, government and business: partners in the dance of change - an Irish perspective', Public Management Review, 4 (2), 257-264

Jacobs, L.A., M.J.K. DiMattio, T.L. Bishop and S.D. Fields (1998), 'The baccalaureate degree in nursing as an entry-level requirement for professional nursing practice', Journal of Professional Nursing, 14 (4), 225-233.

Jarvis, P. (2004), 'The church and the learning society', British Journal of Theological Education, 14 (2), 136-152.

Johns, G. (2001), 'In praise of context', Journal of Organizational Behavior, 22 (1), 31-42.

Jones, Alan M. and Chris Hendry (1992), 'The learning organization: a review of literature and practice', unpublished report, London: HRD Partnership.

Kelemen, M. (2000), 'Too much or too little ambiguity: the language of total quality management', Journal of Management Studies, 37 (4), 483-498.

Khasawneh, S. (2011), 'Learning organization disciplines in higher education institutions: an approach to human resource development in Jordan', Innovative Higher Education, 36 (4), 273-285.

Kieser, A. (1997), 'Rhetoric and myth in management fashion', Organization, 4 (1), 49-74.

Lee, S.S. (1998), 'Jewish institutions as Jewish learning organizations and communities', Jewish Communal Service, 75 (2), 154-159.

Lingard, B., M. Mills and D. Hayes (2000), 'Teachers, school reform and social justice: challenging research and practice', Australian Educational Researcher, 27 (3), 101-115. 
Lipshitz, R., M. Popper and S. Oz (1996) 'Building learning organizations: the design and implementation of organizational learning mechanisms', Journal of Applied Behavioral Science, 32 (3), 292-305.

March, J.G. (2005), 'Parochialism in the evolution of a research community: the case of organization studies', Management and Organization Review, 1 (1), 5-22.

Marquardt, Michael J. and Angus Reynolds (1994), Global Learning Organization: Gaining Advantage Through Continuous Learning, New York: Irwin.

Marsick, Victoria J. and Karen E. Watkins (1999), Facilitating Learning Organizations: Making Learning Count, Aldershot: Gower Publishers.

Meyer, J.W. and B. Rowan (1977), 'Institutionalized organizations: formal structure as myth and ceremony', American Journal of Sociology, 83 (2), 340-363.

Nazari, K. and A. Pihie (2012), 'Assessing learning organization dimensions and demographic factors in technical and vocational colleges in Iran', International Journal of Business and Social Science, 3 (3), 210-216.

Nicolai, A.T. and H. Röbken (2005), 'Scientification, immune responses, and reflection: the changing relationship between management studies and consulting', Journal of Organizational Change Management, 18 (5), 416-435.

Örtenblad, A. (2002a), 'A typology of the idea of learning organization', Management Learning, 33 (2), 213-230.

Örtenblad, A. (2002b), 'Organizational learning: a radical perspective', International Journal of Management Reviews, 4 (1), 87-100.

Örtenblad, A. (2004a), 'The learning organization: towards an integrated model', Learning Organization, 11 (2), 129-144.

Örtenblad, A. (2004b), 'Toward a contingency model of how to choose the right type of learning organization', Human Resource Development Quarterly, 15 (3), 347-350.

Örtenblad, A. (2007a), 'The evolution of popular management ideas: an exploration and extension of the old wine in new bottles metaphor', International Journal of Management Concepts and Philosophy, 2 (4), 365-388.

Örtenblad, A. (2007b), 'What more do we need to know about the learning organization?', Guest editorial, Learning Organization, 14 (4), 296-299.

Örtenblad, A. (2010), 'Who needs contingency approaches and guidelines in order to adapt vague management ideas?', International Journal of Learning and Change, 4 (1), 64-76.

Örtenblad, Anders (2011), Making Sense of the Learning Organization: What is it and Who Needs it?, Kuala Lumpur: Yayasan Ilmuwan.

Pant, L.W. (2001), 'The growing role of informal controls: does organization learning empower or subjugate workers?', Critical Perspectives on Accounting, 12 (6), 697-712.

Parker, Stephen (1998), 'Courts and the Public', academic report, Faculty of Law, Griffith University, Carlton South, Australia: Australian Institute of Judicial Administration Incorporated, http://www.aija.org.au/online/Pub\%20no19.pdf (accessed 22 July 2012).

Pedler, Mike and Kath Aspinwall (1998), A Concise Guide to the Learning Organization, London: Lemos \& Crane.

Pedler, Mike, John Burgoyne and Tom Boydell (1991), The Learning Company: A Strategy for Sustainable Development, London: McGraw-Hill.

Pelz, Donald C. (1978), 'Some expanded perspectives on use of social science in public policy', in John M. Yinger and Stephen J. Cutler (eds), Major Social Issues: A Multidisciplinary View, New York: Free Press, pp. 346-357.

Pennbrant, S., E. Pilhammar Andersson and K. Nilsson (2012), 'Elderly patients' experiences of meeting with the doctor: a sociocultural study in a hospital setting in Sweden', Research on Aging, 35 (2), 163-181.

People's Publishing House (2010), Views on Promoting the Building of Learning Party Organizations, Beijing: People's Publishing House.

Pettinger, Richard (2002), The Learning Organization, Oxford: Capstone.

Ponzi, L.J. and M. Koenig (2002), 'Knowledge management: another management fad?', Information Research, 8 (1), Article 145, http://informationr.net/ir/8-1/paper145.html (accessed 15 April 2008). 
Redding, S.G. (1994), 'Comparative management theory: jungle, zoo, or fossil bed?', Organization Studies, 15 (3), 323-359.

Riggs, D.E. (1997), 'What's in store for academic libraries? Leadership and management issues', Journal of Academic Librarianship, 23 (1), 3-8.

Røvik, Kjell A. (1996), 'Deinstitutionalization and the logic of fashion', in Barbara Czarniawska and Guje Sevón (eds), Translating Organizational Change, Berlin: de Gruyter, pp. 139-172.

Røvik, Kjell A. (1998), 'The translation of popular management ideas: towards a theory', paper presented at the EGOS 14th Colloquium, 9-11 July, Maastricht, Netherlands.

Røvik, K.A. (2011), 'From fashion to virus: an alternative theory of organizations' handling of management ideas', Organization Studies, 32 (5), 631-653.

Ryan, S. and J. Hurley (2004), 'Have total quality management, business process reengineering and the learning organization been replaced by knowledge management?', Irish Journal of Management, 25 (1), 41-55.

Scarbrough, H. and J. Swan (2001), 'Explaining the diffusion of knowledge management: the role of fashion', British Journal of Management, 12 (1), 3-12.

Senge, Peter M. (1990), The Fifth Discipline: The Art and Practice of the Learning Organization, New York: Doubleday.

Senge, Peter M., Art Kleiner, Charlotte Roberts, Rick Ross and Bryan Smith (1994), The Fifth Discipline Fieldbook: Strategies and Tools for Building a Learning Organization, London: Nicholas Brealey.

Sharifirad, M.S. (2011), 'The dimensions of learning organization questionnaire (DLOQ): a cross-cultural validation in an Iranian context', International Journal of Manpower, 32 (5-6), 661-676.

Smith, P.A.C. (1999), 'The learning organization ten years on: a case study', Learning Organization, 6 (5), 217-223.

Sorge, A. and A. van Witteloostuijn (2004), 'The (non)sense of organizational change: an essay about universal management hypes, sick consultancy metaphors, and healthy organization theories', Organization Studies, 25 (7), 1205-1231.

Spell, C.S. (1999), 'Where do management fashions come from and how long do they stay?', Journal of Management History, 5 (6), 334-348.

Stata, Ray (1994), 'Foreword', in Michael J. Marquardt and Angus Reynolds (eds), Global Learning Organization: Gaining Advantage Through Continuous Learning, New York: Irwin, pp. iii-iv.

Stewart, T.A. (1994) 'Your company's most valuable asset: intellectual capital', Fortune, 130 (7), 68-74.

Sturdy, A. (2004), 'The adoption of management ideas and practices: theoretical perspectives and possibilities', Management Learning, 35 (2), 155-180.

Swieringa, Joop and André Wierdsma (1992), Becoming a Learning Organization: Beyond the Learning Curve, Wokingham: Addison-Wesley.

Tam, M. (1999), 'Managing change involves changing management: implications for transforming higher education', Quality in Higher Education, 5 (3), 227-232.

Tiana Ferrer, Alejandro (2010), 'Teachers in charge? Internal school assessment and evaluation in Europe', in Sheila M. Stoney (ed.), Beyond Lisbon 2010: Perspectives from Research and Development for Education Policy in Europe (CIDREE Yearbook 2010), Slough: National Foundation for Educational Research, pp. 121-135.

Watkins, K.E. and R.T. Golembiewski (1995), 'Rethinking organization development for the learning organization', International Journal of Organizational Analysis, 3 (1), 86-101.

Watkins, Karen E. and Victoria J. Marsick (1993), Sculpting the Learning Organization: Lessons in the Art and Science of Systemic Change, San Francisco, CA: Jossey-Bass. 